\title{
KURVA PENAWARAN TENAGA KERJA DAN JAM KERJA PEREMPUAN
}

\author{
Sokhikhatul Mawadah \\ Universitas Islam Negeri Walisongo Semarang \\ e-mail: sokhikhatulmawadah@walisongo.ac.id
}

\begin{abstract}
Abstrak
The labor supply curve is a curve that states the relationship of wages and hours of work. The higher a person's wages the fewer hours they work. The curve should not be appropriate if it is associated with women's working hours, because there are still many women who work a lot but pay little. Especially for women who work on households, how many hours work to work at home and work in the office. The purpose of this paper is to find out the relationship of wages and working hours of women, analyzing the labor supply curve based on Central Java Provincial BPS data on women's working hours and knowing the relevance of the labor supply curve to the current (working women) society condition. From the discussion in this writing is known that many factors that affect the labor supply curve, one of which is the factor of women who take care of the household. So there is a relationship between the labor supply curve with female work hours but is less relevant. The labor supply curve does address wages and hours of work but does not deal specifically with wages, working hours and women. There should be a distinction or an exception to women. especially working hours of working women (as professions) with women who only work as housewives. let alone strengthened from the data of BPS statistics center agency which shows the number of working hours of women more than the number of man hours worked.
\end{abstract}

Kurva penawaran tenaga kerja adalah kurva yang menyatakan hubungan upah dan jam kerja. Semakin tinggi upah seseorang maka semakin sedikit jam kerjanya. Kurva tersebut tidak sepatutnya tepat jika dikaitkan dengan jam kerja perempuan, karena masih banyak perempuan yang jam kerjanya banyak tetapi upahnya sedikit. Apalagi untuk perempuan yang bekerja mengurusi rumah tangga, berapa banyak jumlah jam kerja untuk di bekerja di rumah dan bekerja di kantor. Tujuan penulisan ini adalah untuk mengetahui hubungan upah dan jam kerja perempuan, Menganalisa kurva penawaran tenaga kerja berdasarkan data BPS Provinsi Jateng tentang jam kerja perempuan dan mengetahui relevansi kurva penawaran tenaga kerja dengan keadaan 
masyarakat (perempuan bekerja) dewasa ini. Dari pembahasan dalam penulisan ini diketahui bahwa banyak faktor yang mempengaruhi kurva penawaran tenaga kerja, salah satunya adalah faktor wanita yang mengurus rumah tangga. Jadi ada hubungan antara kurva penawaran tenaga kerja dengan jam kerja perempuan tetapi kurang relevan. Kurva penawaran tenaga kerja memang membahas tentang upah dan jam kerja tetapi tidak membahas spesifik tentang upah, jam kerja dan perempuan. Seharusnya ada pembeda/pengecualian terhadap perempuan, khususnya jam kerja perempuan yang bekerja (sebagai profesi) dengan perempuan yang hanya bekerja sebagai ibu rumah tangga. Apalagi dikuatkan dari data Badan Pusat Statistik (BPS) yang menunjukkan jumlah jam kerja wanita lebih banyak dibanding jumlah jam kerja laki-laki.

Kata Kunci: jam kerja; kurva penwaran tenaga kerja; perempuan; upah

\section{A. Pendahuluan}

Pada kurva penawaran tenaga kerja menyatakan bahwa semakin tinggi upah seseorang maka semakin berkurang jam kerjanya. Dewasa ini banyak perempuan yang bergaji atau memiliki upah besar tapi jam kerjanya sedikit (contoh: guru besar, kepala cabang suatu bank, manager dll). Sebaliknya perempuan yang jam kerjanya sangat banyak (seharian penuh) tapi upah/ gajinya sedikit (contoh: asisten rumah tangga, buruh pabrik, pramuniaga toko, dll).

Dalam dunia kerja, perempuan pada arus glaobalisasi yang semakin hari semakin dahsyat, jam kerja perempuan sama banyaknya dengan jam kerja lakilaki, bahkan melebihi daripada jam kerja laki-laki. Padahal perempuan jika sudah di rumah (mengurusi rumah tangga) akan semakin bertambah jm kerjanya. Data BPS (Badan Pusat Statistik) Provinsi Jawa Tengah mencatat bahwa jumlah jam kerja seluruhnya yang ada di provinsi Jawa Tengah tercatat jam kerja perempuan (female) lebih banyak daripada laki-laki (male). ${ }^{1}$ Seharusnya berdasar data tersebut, dengan latar belakang adat ketimuran yang bekerja adalah laik-laki sebagai kepala keluarga, maka seharusnya jam kerja perempuan harus tidak lebih banyak daripada jam kerja laki-laki. Berdasarkan data BPS Provinsi Jateng juga seharusnya masyarakat Jateng sejahtera jika upah banyak namun jam kerja sedikit.

${ }^{1}$ https://jateng.bps.go.id/index.php/linkTabelStatis/1478, tanggal 1 Agustus 2017. 


\section{B. Kurva Penawaran Tenaga Kerja}

Penawaran tenaga kerja adalah fungsi yang menggambarkan hubungan antara tingkat upah dengan jumlah tenaga kerja yang ditawarkan. Sedangkan Menurut Ananta penawaran terhadap pekerja adalah hubungan antara tingkat upah dengan jumlah satuan pekerja yang disetujui oleh pensuplai untuk ditawarkan. Jumlah satuan pekerja yang ditawarkan disebabkan oleh beberapa faktor antara lain: a) banyaknya jumlah penduduk, b) presentase penduduk yang berada dalam angkatan kerja, dan c). jam kerja yang ditawarkan oleh angkatan kerja. ${ }^{2}$

Pendapat lain dikemukakan oleh Simanjuntak mendefinisikan penawaran tenaga kerja merupakan jumlah usaha atau jasa kerja yang tersedia dalam masyarakat untuk menghasilkan barang dan jasa. ${ }^{3}$ Sedangkan menurut Arfida penawaran tenaga kerja adalah fungsi yang menggambarkan hubungan antara tingkat upah dengan jumlah tenaga kerja yang ditawarkan. ${ }^{4}$ Penawaran tenaga kerja dalam jangka pendek merupakan suatu penawaran tenaga kerja bagi pasar dimana jumlah tenaga kerja keseluruhan yang ditawarkan bagi suatu perekonomian dapat dilihat sebagai hasil pilihan jam kerja dan pilihan partisipasi oleh individu. Sedangkan penawaran tenaga kerja dalam jangka panjang merupakan konsep penyesuaian yang lebih lengkap terhadap perubahan-perubahan kendala. Penyesuaian-penyesuaian tersebut dapat berupa perubahan-perubahan partisipasi tenaga kerja maupun jumlah penduduk.

Menurut Khairani, faktor-faktor yang mempengaruhi penawaran tenaga kerja adalah: ${ }^{5}$

1. Jumlah Penduduk. Semakin besar jumlah penduduk maka semakin banyak pula tenaga kerja yang tersedia, baik untuk angkatan kerja atau bukan angkatan kerja. Maka jumlah penawaran tenaga kerja juga akan semakin besar. h. 13.

${ }^{2}$ Aris Ananta, Ekonomi Sumber Daya Manusia (Jakarta: Lembaga Demografi FE UI,1990),

${ }^{3}$ Simanjuntak, P. J., Pengantar Ekonomi Sumber Daya Manusia (Jakarta. Lembaga Penerbit FE-UI, 1996), h. 25.

${ }^{4}$ Arfida, Ekonomi Sumber Daya Manusia (Jakarta: Ghalia Indonesia, 2003), h. 30.

${ }^{5}$ Khairani, "Faktor-faktor yang Mempengaruhi Penawaran Tenaga Kerja Wanita di Kota Binjai". Sripsi Fakultas Ekonomi Universitas Sumetera Utara, 2010. 
2. Struktur Umur. Penduduk Indonesia termasuk dalam struktur umur muda, ini dapat dilihat dari bentuk piramida penduduk IndonesiaTersusun dari garis atau koordinat vertikal yang digunakan untuk menyatakan golongan umur. Dimulai dari umur 0-4, 5-9, dan seterusnya hingga usia maksimal yang bisa dicapai oleh penduduk di suatu wilayah. Meskipun pertambahan penduduk dapat ditekan tetapi penawaran tenaga kerja semakin tinggi karena semakin banyaknya penduduk yang memasuki usia kerja, maka penawaran tenaga kerja juga akan bertambah.

3. Produktivitas. Produktivitas menurut Kamus Besar Bahasa Indonesia adalah kemampuan untuk menghasilkan sesuatu; daya produksi; keproduktifan. Semakin banyak output yang dihasilkan maka semakin produktif sesuatu tersebut. Produktivitas tenaga kerja dapat dilihat dari tingkat pendidikan, teknologi, dan keterampilan. Semakin tinggi pendidikan atau keterampilan tenaga kerja maka semakin meningkat produktivitas tenaga kerja.

4. Tingkat Upah. Secara teoritis, tingkat upah akan mempengaruhi jumlah penawaran tenaga kerja. Apabila tingkat upah naik, maka jumlah penawaran tenaga kerja akan meningkat begitu pula sebaliknya. Hal ini dapat dibuktikan pada kurva penawaran tenaga kerja yang berslope positif (artinya jika variabel yang ada pada garis horisontal mengalami knaikan, maka berbanding lurus pada variabel yang ada pada garis vertikal). Pertambahan tingkat upah akan mengakibatkan pertambahan jam kerja bila substitution effect lebih besar daripada income effect. ${ }^{6}$ Semakin tinggi tingkat upah yang ditawarkan akan menyebabkan seseorang berpikir kembali untuk memasuki dunia kerja dengan penawaran upah tersebut. Tingkat upah tersebut biasa dihubungkan dengan jam kerja yang harus diambil seseorang dalam bekerja.

5. Kebijakan Pemerintah. Dengan adanya kebijakan pemerintah maka sesuai dengan apa yang diharapkan. Kebijakan pemerintah sebagai tangan panjang kesuksesan dalam suatu produksi perusahaan Misal kebijakan pemerintah dalam hal belajar 9 tahun akan mengurangi jumlah tenaga kerja, dan akan ada batas umur kerja menjadi lebih tinggi. Dengan demikian terjadi pengurangan jumlah tenaga kerja

6. Wanita yang mengurus rumah tangga. Wanita yang mengurus rumah tangga tidak termasuk dalam angkatan kerja, tetapi mereka adalah tenaga

'Simanjuntak, P. J., Pengantar Ekonomi Sumber Daya Manusia, h. 27. 
kerja yang potensial yang sewaktu-waktu bisa memasuki pasar kerja. Dengan demikian semakin besar jumlah wanita yang mengurus rumah tangga maka penawaran tenaga kerja akan berkurang begitu pula sebaliknya.

7. Penduduk yang bersekolah. Sama dengan hal di atas penduduk yang bersekolah tidak termasuk dalam angkatan kerja tetapi mereka sewaktu-waktu dapat menjadi tenaga kerja yang potensial, dengan demikian semakin besar jumlah penduduk yang bersekolah berarti supply tenaga kerja akan berkurang. Oleh karena itu jumlah penduduk yang bersekolah perlu diperhitungkan untuk masa yang akan datang.

8. Keadaan perekonomian. Keadaan perekonomian dapat mendesak seseorang untuk bekerja memenuhi kebutuhannya, misalnya dalam satu keluarga harus bekerja semua karena pendapatan suami tidak mencukupi kebutuhan keluarga. Contoh lain seorang mahasiswa yang tamat tidak mau bekerja karena perekonomian orang tua sangat memadai dan contoh lain seorang istri tidak perlu bekerja karena perekonomian suami sudah mencukupi.

Menurut pendapat lain, faktor yang mempengaruhi penawaran tenga kerja adalah:

1. Jumlah angkatan kerja. Dengan jumlah penduduk Indonesia yang sangat besar, maka jumlah angkatan kerja yang tersedia melebihi jumlah tenaga kerja diminta. Hal ini berarti terjadi kelebihan pencari kerja di atas jumlah pekerja diminta (labor surplus). Adanya labor surplus menyebabkan angka pengangguran tinggi dan disertai dengan tingkat upah yang rendah.

2. Komposisi demografi penduduk. Diantaranya jumlah penduduk pada berbagai usia, penduduk suatu negara (perekonomian) terdiri dari penduduk pada usia kerja dan penduduk di luar usia kerja. Mereka yang termasuk di luar usia kerja adalah anak-anak dan penduduk berusia lanjut (pasca kerja). Selanjutnya, kelompok penduduk yang berada pada usia kerja disebut tenaga kerja. Tenaga kerja terdiri dari angkatan kerja dan bukan angkatan kerja. Angkatan kerja mencakup penduduk yang bekerja dan yang sedang mencari kerja (menganggur). Sementara itu kelompok bukan angkatan kerja terdiri dari mereka yang masih bersekolah, mengurus rumah dan atau golongan penerima pendapatan. Dalam suatu perekonomian, penawaran tenaga kerja ditentukan oleh jumlah angkatan kerja. Semakin besar jumlah angkatan kerja, semakin besar pula penawaran tenaga kerja. 
3. Partisipasi angkatan kerja. Pengaruh partisipasi angkatan kerja dijelaskan melalui teori alokasi waktu yang dikemukakan oleh Becker.7 Teori Alokasi waktu yaitu atau $A$ Theory of The Allocation of Time menyatakan bahwa semua orang memiliki waktu yang akan dialokasikan untuk bekerja ataupun untuk kegiatan lainnya.

\section{Bentuk Kurva Penawaran Tenaga Kerja}

Penawaran kerja dipengaruhi oleh keputusan seseorang apakah dia mau bekerja atau tidak. Keputusan ini tergantung pula pada tingkah laku seseorang untuk menggunakan waktunya, apakah akan digunakan untuk kegiatan lain yang sifatnya lebih santai (konsumtif), atau kombinasi keduanya. Apabila dikaitkan dengan tingkat upah, maka keputusan untuk bekerja seseorang akan dipengaruhi pula oleh tinggi rendahnya penghasilan seseorang. Apabila penghasilan tenaga kerja relatif sudah cukup tinggi, maka tenaga kerja tersebut cenderung untuk mengurang waktu yang dialokasikan untuk bekerja. Hal tersebut menyebabkan bentuk dari kurva penawaran membelok ke kiri yang dikenal dengan backward bending supply curve

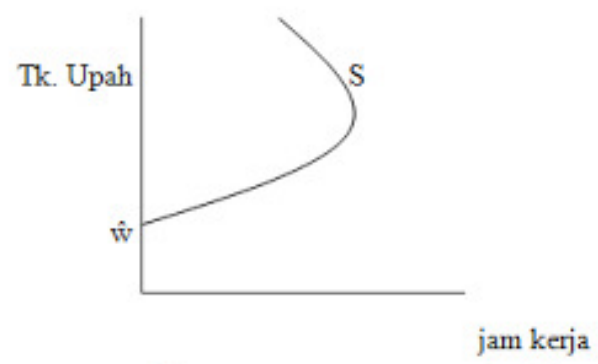

Kurva penawaran tenaga kerja melengkung ke belakang

\section{Relevansi Upah, Jam Kerja dan Perempuan}

Menurut Hasibuan, upah adalah balas jasa yang dibayarkan kepada para pekerja harian dengan berpedoman atas perjanjian yang disepakati membayar-

"Becker, Gary S., "A Theory of the Allocation of Time". The Economic Journal, 75, 299, 1965, h. 493-517. 
nya. ${ }^{8}$ Moekijat menyatakan bahwa upah adalah pembayaran yang diberikan kepada karyawan produksi dengan dasar lamanya jam kerja. ${ }^{9}$

Pendapat lain dikemukakan oleh Simanjuntak ${ }^{10}$ menyatakan bahwa upah merupakan imbalan yang diterima seseorang atas jasa yang diberikannya bagi pihak lain, diberikan seluruhnya dalam bentuk uang atau sebagian dalam bentuk uang dan sebagian dalam bentuk natural. Natural yang dimaksud adalah selain yang berbentuk uang. Dapat berbentuk benda, jaminan kesehatan, insentif, reward jalan-jalan dan sebagainya.

Jam kerja "normal" umumnya diartikan hari kerja dengan jam tersisa untuk rekreasi dan istirahat. Istirahat adalah kegiatan malam hari, sedangkan bekerja adalah aktivitas siang hari. Hal ini berkaitan dengan mereka yang bekerja dengan jadwal yang tidak biasa, baik pada shift kerja atau dengan jam yang diperpanjang hingga melampaui siang, bekerja pada malam hari, serta bekerja disaat pola tidur. Jam kerja adalah waktu yang ditentukan untuk melakukan pekerjaan. Harrington juga menyatakan bahwa lamanya jam kerja berlebih dapat meningkatkan human error atau kesalahan kerja karena kelelahan yang meningkat dan jam tidur yang berkurang. Hal tersebut juga didukung oleh penelitian Berger, et.al (2006) dalam Maurits dan Widodo ${ }^{11}$ yang menyatakan bahwa tambahan durasi pada suatu shift kerja, akan meningkatkan tingkat kesalahan. Lima kali tambahan durasi shift per bulan akan meningkatkan kelelahan 300\% dan berakibat fatal. Timework (upah menurut waktu) adalah suatu sistem penentuan upah yang dibayar menurut lamanya/jangka waktu yang terpakai dalam menyelesaikan suatu pekerjaan, misalnya per hari, per jam, per minggu, per bulan, dan lain lain. Terdapat aturan tentang batasan waktu kerja maksimal, dan pemberian waktu istirahat, serta kompensasi pelampauan dari ketentuan tersebut. Tertuang dalam Kepres No. 3 Tahun 1983 yang isinya antara lain sebagai berikut:

${ }^{8}$ Malayu S.P. Hasibuan, Manajemen Sumber Daya Manusia (jilid-9), (Jakarta: Gunung Agung, 1997).

${ }^{9}$ Moekijat, Administrasi Gaji dan Upah (Bandung: Mandar Maju, 1992), h. 53.

${ }^{10}$ Simanjuntak, P. J., Pengantar Ekonomi Sumber Daya Manusia, h. 33.

${ }^{11}$ Maurits, L.S. \& Widodo, I.D, “Faktor dan Penjadualan Shift Kerja”, Jurnal Teknoin, Vol. 13 No. 2, 2008. 
1. Jam kerja $7 \mathrm{jam} / \mathrm{hari}$ dan $40 \mathrm{jam} /$ minggu.

2. Jika bekerja 4 jam berturut-turut harus diberikan istirahat sedikitnya setengah jam.

3. Waktu istirahat mingguan 2 hari (untuk 5 hari kerja) dan 1 hari (untuk 6 hari kerja).

4. Waktu istirahat tahunan adalah hari libur resmi, diberikan kepada pekerja untuk merayakannya. Penetapan waktunya ditentukan oleh pemerintah.

Pengertian kerja menurut, Moore (1988) dalam Ratna Saptari ${ }^{12}$ adalah tidak hanya sebatas apa yang dilakukan seseorang melainkan menyangkut juga kondisi yang melatarbelakangi kerja tersebut, serta penilaian sosial yang diberikan terhadap pekerjaan tersebut. Bagi perempuan (istri), bekerja tidak sematamata untuk mencari nafkah, karena nafkah sudah menjadi kewajiban suami. Bekerja dilatarbelakangi untuk aktualisasi diri terhadap ilmu yang telah dipelari selama bertahun-tahun. Sebagai bukti untuk penilaian di masayarakat agar tidak ada anggapan sekolah tinggi-tinggi hanya mengurus anak di rumah.

Masih menurut Moore, kerja adalah segala hal yang dikerjakan oleh seseorang individu baik untuk subsistensi; untuk dipertukarkan atau dipertukarkan atau diperdagangkan; untuk menjaga kelangsungan keturunan dan kelangsungan hidup keluarga atau masyarakat. Jadi kerja tidak hanya untuk yang berupah (kerja upahan) seperti: kegiatan yang dilakukan di pabrik, di pasar, di kantor melainkan kerja mengasuh anak, pembersih rumah, pencucian/ penjahitan baju, pelayanan sosial ataupun seksual, pendidikan atau pembinaan hubungan dengan keluarga lain dalam suatu komunitas.

Dalam literatur studi perempuan, sering ada dikotomi antara apa yang disebut kerja produksi dan kerja reproduksi. Kerja produksi diartikan menghasikan sesuatu untuk kelangsungan hidup anggotanya, sedangkan kerja reproduksi diartikan secara harfiah: menggantikan apa yang telah habis atau hilang untuk kelestarian sistem atau struktur sosial yang bersangkutan. Konsep reproduksi menurut Edholm (1977) ada 3 jenis yaitu: reproduksi biologis, yaitu melahirkan anak, reproduksi tenaga kerja, yaitu sosialisai dan pengasuhan anak (mem-

\footnotetext{
${ }^{12}$ Ratna Saptari \& Brigitte Holzner, Perempuan Kerja dan Perubahan Sosial Sebuah Pengantar Studi Perempuan (Jakarta: Pustaka Utama Grafiti, 1997), h. 227.
} 
persiapkan anak untuk menjadi cadangan tenaga kerja berikutnya dan reproduksi sosial, yaitu proses dimana hubungan produksi dan struktur sosial terus diproduksi dan dilestarikan. ${ }^{13}$

Perempuan banyak yang bekerja tetapi banyak pula dari mereka yang mengalami diskriminasi upah, pelecehan dan kekerasan di tempat kerja. ${ }^{14}$ Beberapa diskriminasi tersebut dipengaruhi oleh beberapa faktor yang kerap terjadi pada masayarkat kita. Salah satu faktor tersebut adalah: istilah konco wingking. Istilah tersebut yang menjadikan perempuan tidak boleh "melebihi" laki-laki. Upah harus lebih sedikit dari laki-laki, sekolah tidak boleh terlalu tinggi dari suami dan sebagainya. Namun untuk mengurusi rumah tangga, perempuan harus lebih dari laki-laki. Jam mengurus anak lebih dari laki-laki, lebih banyak mengerjakan pekejaan rumah tangga dan sebagainya.

\section{E. Relevansi Kurva Tenaga Kerja dengan Upah, Jam Kerja dan Perempuan}

\section{Kurva Penawaran Tenaga Kerja}

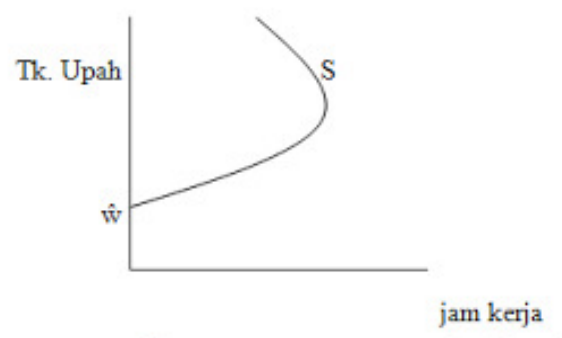

Kurva penawaran tenaga kerja melengkung ke belakang

Pada penawaran tenaga kerja dikenal istilah upah reservasi. Upah reservasi adalah tingkat upah terendah di mana seseorang tetap ingin bekerja atau tingkat upah tertinggi di mana seseorang masih tetap menganggur. Penawaran tenaga kerja dapat diwakili oleh karakteristik upah reservasi (reservation wage). Tingkat upah di bawah upah reservasi tidak akan mengubah perilaku, sedangkan bila

${ }^{13}$ Ibid., 225.

${ }^{14}$ Muhadjir Darwin, "Gerakan Perempuan di Indonesia dari Masa ke Masa", Jurnal Ilmu Sosial Politik, 2004, h. 26. 
tingkat upah berada di atas upah reservasi barulah seseorang memutuskan untuk bekerja.

Kurva penawaran tenaga kerja yaitu hubungan antara jam kerja dan tingkat upah. Dapat dicontohkan: seseorang tertarik memasuki pasar kerja, jika upah yang ditawarkan melebihi dari upah reservasi. Pada tingkat upah diatas upah reservasi, kurva penawaran tenaga kerja memiliki slope positif sampai pada titik tertentu. Keadaan selanjutnya akan berubah jika seseorang kesejahteraannya sudah baik atau mempunyai suatu keahlian yang lebih dan jumlah jam kerja yang ditawarkan semakin berkurang, maka pada saat upah meningkat dapat mengakibatkan slope kurva penawaran tenaga kerja menjadi negatif. Kurva ini disebut kurva penawaran tenaga kerja melengkung ke belakang (backward bending labour supply curve).

Jumlah tenaga kerja keseluruhan yang disediakan bagi suatu perekonomian tergantung pada jumlah penduduk, persentase jumlah penduduk yang memilih masuk dalam angkatan kerja, dan jumlah jam kerja yang ditawarkan oleh angkatan kerja. Dalam penawaran tenga kerja ada dua jangka waktu, yaitu jangka pendek dan jangka panjang. Jangka pendek dalam penawaran tenaga kerja yaitu jangka waktu dimana individu dalam penduduk yang telah tertentu jumlahnya tidak dapat mengubah jumlah modal manusia. Sehingga asumsi yang digunakan ketrampilan dari individu tertentu. Sedangkan jangka panjang dalam penawaran tenaga kerja yaitu penyesuaian yang dilakukan individu untuk memaksimalkan utilitas dalam jumlah tenaga kerja yang mereka sediakan.

Upah pasar dan pendapatan dapat mengalami perubahan. Suatu penyesuaian akan bersifat jangka panjang dalam perubahan-perubahan partisipasi tenaga kerja. Terutama terdapat penambahan yang besar dalam tingkat partisipasi angkatan kerja di kalangan wanita yang telah menikah dan penurunan dalam tingkat partisipasi kaum pekerja yang berusia lanjut, berusia anak-anak, dan berusia lebih muda. Penyesuaian lainnya ialah dalam bentuk jumlah penduduk. Suatu analisis jangka panjang tentang penawaran tenaga kerja menjajaki hubungan antara kesuburan (fertilitas) dan perubahan jangka panjang dalam upah pasar pendapatan.

Kurva penawaran tenga kerja yang menyatakan semakin sedikit jam kerja seseorang maka semakin banyak upahnya, tidak beraku global, apalagi untuk para pekerja perempuan. Perempuan bekerja jika dikaitkan dengan maksud 
kurva tersebut adalah kurang relevan. Dengan jam kerja yang banyak, nyatanya perempuan upahnya sedikit. (contoh: ibu rumah tangga yang bekerja di kantor dan bekerja pula mengurusi rumah tangga). Dalam hal ini perempuan menjadi "dobel" jam kerjanya. Jam kerja yang sebenarnya (bekerja sebagai profesi) dengan jam kerja yang selayaknya kodrat wanita (mengurus rumah tangga, mengurus suami dan anak dil).

Bekerja merupakan suatu kegiatan untuk memperoleh pendapatan, sedangkan leisure adalah kegiatan lain yang merupakan kegiatan non pasar. Pilihan antara leisure dan bekerja dalam penawaran tenaga kerja dapat ditentukan dari total jam yang tersedia atau waktu endowment. Waktu yang digunakan untuk leisure akan mengurangi waktu yang digunakan untuk bekerja ${ }^{15}$ Dengan demikian, perempuan bekerja sebaiknya dihitung dalam hal kegiatan non pasar bukan untuk kegiatan memperoleh pendapatan. Waktu tersebut juga dapat digunakan untuk mengurangi jam kerja. Diharapkan jam kerja perempuan tidak akan berlebihan atau berlipat ganda.

Kurva penawaran tenaga kerja memang membahas tentang upah dan jam kerja, tidak membahasa spesifik tentang upah, jam kerja dan perempuan. Namun harusnya ada pembeda/pengecualian terhadap perempuan, khususnya jam kerja perempuan. Harus ada pembeda antara jam kerja perempuan yang bekerja (sebagai profesi) dengan perempuan yang hanya bekerja sebagai ibu rumah tangga. Ada tiga persepsi yang membahas tentang kedudukan tenaga kerja wanita. Diantaranya: 1) individu, 2) sosial masyarakat dan 3) agama dan budaya.

Perempuan sebagai individu meliputi kebutuhan dalam diri manusia yaitu kebutuhan dasar dan kebutuhan tumbuh. Perempuan sebagai sosial dan masyarakat yaitu adanya anggapan masyarakat bahwa keluarga yang ideal adalah suami bekerja di luar rumah dan istri dirumah dengan mengerjakan berbagai pekerjaan rumah. Sedangkan persepsi yang ketiga yaitu pandangan wanita bekerja dari sisi ini didasarkan atas ajaran bahwa seorang suami adalah memimpin dalam rumah tangga sehingga istri harus patuh pada suaminya. Menurut perspektif Islam, wanita sebagai pusat kasih sayang dan proses

\footnotetext{
${ }^{15}$ Kaufman \& Hotchkiss, The Economics of Labor Markets, sixt edition, USA. 1999, h. 78.
} 
pendidikan dalam keluarga, memiliki kedudukan istimewa sebagai seorang istri dan ibu. Di saat yang sama, Islam tidak menentang peran aktif mereka di tengah masyarakat.

Dalam data jam kerja Badan Pusat Statistik (BPS) Jawa Tengah, jam kerja perempuan masih lebih tinggi dari jam kerja laki-laki dengan jumlah jam kerja seluruhnya 1-14 jam. Jika disederhanakan menjadi presentase, sebagai berikut:

\begin{tabular}{|c|c|c|c|c|c|}
\hline No. & Tahun & Laki-laki (L) & $\begin{array}{c}\text { Perempuan } \\
(\mathbf{P})\end{array}$ & $\begin{array}{c}\text { Presentase } \\
(\mathbf{L}):(\mathbf{P})\end{array}$ & Selisih \\
\hline 1 & 2007 & 293019 & 513902 & $36,31 \%: 63,68 \%$ & $27,37 \%$ \\
\hline 2 & 2008 & 306705 & 553173 & $64,33 \%: 35,66 \%$ & $28,67 \%$ \\
\hline 3 & 2009 & 328368 & 604922 & $64,81 \%: 35,18 \%$ & $29,63 \%$ \\
\hline 4 & 2010 & 268486 & 507456 & $65,39 \%: 34,60 \%$ & $30,73 \%$ \\
\hline 5 & 2011 & 325335 & 614728 & $65,39 \%: 34,60 \%$ & $30,73 \%$ \\
\hline 6 & 2012 & 368528 & 616499 & $62,58 \%: 37,41 \%$ & $25,17 \%$ \\
\hline 7 & 2013 & 625156 & 756201 & $54,74 \%: 45,25 \%$ & $9,49 \%$ \\
\hline 8 & 2014 & 380957 & 623122 & $61,44 \%: 37,56 \%$ & $23,88 \%$ \\
\hline 9 & 2015 & 310564 & 602489 & $65,98 \%: 34,01 \%$ & $31,97 \%$ \\
\hline 10 & 2016 & 258827 & 583698 & $69,27 \%: 30,72 \%$ & $38,55 \%$ \\
\hline
\end{tabular}

Sumber: Data BPS Sakernas yang telah diolah, 2017

Tingkat stress dan kelelahan perempuan yang bekerja dengan yang tidak bekerja juga akan terlihat bedanya. Menurut Muchlas Makmuri sebab stress dikarenakan tekanan ekstraorganisasi. Stress tersebut dipengaruhi oleh hal-hal diluar lingkungan kerjanya (ekstraorganisasi). Tekanan-tekanan tersebut berupa: perubahan sosial dan teknologi, keluarga, relokasi, kondisi-kondisi ekonomis dan finansial, suku bangsa dan kelas sosial. Perempuan bekerja sudah merasakan kelelahan dan stress di dalam pekerjaannya, juga dapat pula mengalami stress di luar pekerjaanya. ${ }^{16}$

Dalam kurva tenaga kerja juga sebaiknya memuat tentang faktor-faktor lain yang menyebabkan perubahan upah dan jam kerja. Khusus untuk upah dan jam kerja perempuan, beberapa variabel yang dapat dijadikan landasan penghitungan dalam kurva penawaran tenaga kerja adalah faktor eksternal di luar pekerjaan (ektraorganisasi). Variabel tersebut diantaranya: perubahan kelas sosial, keluarga,

${ }^{16}$ Muchlas Makmuri, Perilaku Organisasi, cet. II (Yogyakarta: Gadjah Mada University Press, 2008), h. 59. 
teknologi dan kondisi ekonomi dan finansial. Sehingga adapat diketahu lebih mendalam mengapa kurva permintaan tenaga kerja berkaitan dengan upah dan jam kerja perempuan.

Pekerja perempuan dihadapkan pada kenyataan bahwa produktivitas seorang perempuan dalam usahanya berpartisipasi diluar rumah dibatasi oleh sektor domestiknya, sehingga mempengaruhi perempuan (ibu rumah tangga) untuk memasuki berbagai jenis pekerjaan yang ada di pasaran kerja. Faktorfaktor domestik selain faktor eksternal di atas juga penting dijadikan pedoman dalam menganalisa relevansi kurva penawaran tenaga kerja dan jam kerja perempuan. Keterlibatan perempuan (ibu rumah tangga) untuk mencari nafkah, dapat menentukan besar kecilnya pendapatan keluarga, yang berarti pula menentukan besar kecilnya pendapatan keluarga, yang berarti pula menentukan tingkat hidup atau standar of living, status sosial ekonomi serta tingkat hidup dari keluarganya.

\section{F. Kesimpulan}

Penawaran tenaga kerja adalah fungsi yang menggambarkan hubungan antara tingkat upah dengan jumlah tenaga kerja yang ditawarkan. Sedangkan kurva penawaran tenaga kerja menyatakan bahwa semakin tinggi upah seseorang maka semakin berkurang jam kerjanya. Bekerja bagi perempuan merupakan pilihan. Piihan antara Hubungan kurva penwaran kerja terhadap jam kerja perempuan adalah semakin sedikit jam kerja seseorang maka semakin banyak upahnya, tidak beraku global, apalagi untuk para pekerja perempuan.

Perempuan bekerja jika dikaitkan dengan maksud kurva tersebut adalah kurang relevan Kurva penawaran tenaga kerja yang memuat jam kerja dan upah belum spesifik membahas tentang jam kerja dan upah untuk perempuan. Padahal jam kerja perempuan berbeda dengan jam kerja laki-laki. Sehingga berbeda pula dalam hal penerimaan upah yang didapat oleh laki-laki dan perempuan. Terdapat beberapa persepsi yang mengikuti seoarang ermpuan untuk bekerja atau ahnya sebagai ibu rumah tangga yang tidak bekerja (kegiatan non pasar).] 


\section{Daftar Pustaka}

Ananta, Aris, Ekonomi Sumber Daya Manusia, Jakarta: Lembaga Demografi FE UI,1990.

Arfida, Ekonomi Sumber Daya Manusia, Jakarta: Ghalia Indonesia, 2003.

Becker, Gary S., "A Theory of the Allocation of Time", The Economic Joumal, 75, 299, 1965.

BPS Jateng, Survei Angkatan Kerja Nasional Badan Pusat Statistis (BPS) Jawa Tengah, https://jateng.bps.go.id/index.php/linkTabelStatis/1478, tanggal 1 Agustus 2017.

Darwin, Muhadjir, "Gerakan Perempuan di Indonesia dari Masa ke Masa", Jurnal Ilmu Sosial Politik, 2004.

Etzel. Michael J. Walker J.W., Stanton, W.J, Marketing, Edisi ke-12, New York,USA: McGraw-Hill Irwin, 2001.

Harrington, J.M, "Health Effect of Shift Work and Extended Hours of Work", Joumal of Occupational and Environmental Medicine University of Birmingham, 2001.

Khairani, "Faktor-faktor yang mempengaruhi penawaran tenaga kerja wanita di Kota Binjai”. Sripsi Fakultas Ekonomi Universitas Sumetera Utara, 2010.

Makmuri, Muchlas, Perilaku Organisasi, cet. II, Yogyakarta: Gadjah Mada University Press, 2008.

Malayu S.P. Hasibuan, Manajemen Sumber Daya Manusia (jilid-9), Jakarta: Toko Gunung Agung, 1997.

Maurits, L.S. \& Widodo, I.D., "Faktor dan Penjadualan Shift Kerja", Jurnal Teknoin, Vol. 13, No. 2, 2008.

Moekijat, Administrasi Gaji dan Upah, Bandung: Mandar Maju, 1992.

Nadia, "Analisis Penawaran Tenaga Kerja Wanita Menikah dan Faktor yang Mempengaruhinya di Kabupaten Brebes". Skripsi S1 Fakultas Ekonomika dan Bisnis Universitas Diponegoro, 2012.

Ratna Saptari \& Brigitte Holzner, Perempuan Kerja dan Perubahan Sosial Sebuah Pengantar Studi Perempuan, Jakarta: Pustaka Utama Grafiti, 1997.

Simanjuntak, P. J., Pengantar Ekonomi Sumber Daya Manusia, Jakarta: Lembaga Penerbit FE-UI, 1996. 